\title{
PÓS-GRADUAÇÃO EM CIRURGIA: ONDE CHEGAMOS E PARA ONDE CAMINHADOS
}

\section{POST-GRADUATION IN SURGERY: WHERE DID WE COME TO AND WHERE ARE WE GOING TO}

\section{Ricardo Antonio Refinetti, TCBC-RJ ${ }^{1}$}

Após 30 (trinta) anos de existência, alicerçada em uma produção científica de mais de trezentas teses e/ou dissertações, a Pós-Graduação (PG) em Cirurgia da U.F.R.J., criada e implementada por idealistas, defensores do aprimoramento do ensino através da qualificação dos professores por uma PG de alto nível, nos conduz a uma situação, que julgamos ser propícia para refletirmos sobre o que passamos e onde chegamos. E assim sendo, julgamos ser nosso dever relacionar alguns nomes que lutaram em prol desta nobre causa. Dentre estes, não poderíamos deixar de reverenciar Mariano de Andrade, Wigand Joppert, Umberto Perrota e Célio Pacheco Chaves, etc.

Revendo editoriais sobre este fascinante tema, insertos na Revista do Colégio Brasileiro de Cirurgiões (CBC) (Accyoli Maia, Gama Rodrigues, Samir Raslan, Oswaldo Malafaia) procuramos alterar o perfil de abordagem de tal assunto, para não incorremos em repetições, haja visto que os mesmos cumpriram, com louvor, seus objetivos.

Isto posto, resolvemos analisar alguns aspectos relacionados com o processo atual de avaliação dos Cursos e/ou Programa vigentes. Dentro deste princípio, nos propomos externar a visão que temos do futuro da Pós-Graduação senso strictu, em nosso meio. Para tal, consideramos, não só as sugestões adivindas dos últimos cinco Encontros Nacionais de PG, que trataram desta importante temática, mas, sobretudo quanto às diretrizes emanadas do encontro realizado em Atibaia (agosto/ 2003). A essas propostas acrescentamos, mas não só, a nossa vivência na Coordenação do Programa da U.F.R.J., mas também a experiência acumulada, como particípe, nas comissões de avaliação dos programas da área de Medicina III.
Estes fatos, não só ampliaram, de maneira ponderável, nossa visão acerca deste assunto, como também reforçaram nossa compreenção sobre a importância da relação do binômio Orientador/ Orientando, ao qual acrescentaríamos ainda, a produção intelectual das linhas de pesquisa, a qualidade das teses e dissertações, as atividades do corpo docente na graduação e a situação atual dos egressos da PG.

Consideramos ser altamente profícuo para o sistema, se os professores registrassem seus projetos já comprometidos com linhas de pesquisa do Programa. Por outro lado teriam, obrigatoriamente, de submetê-los a apreciação de uma comissão de avaliação, destinada à este fim. Aprovado o ensaio, este ficará sujeito a um estágio probatório com disponibilidade temporal suficiente para consolidar sua validade. Uma vez comprovado o valor do produto da experimentação, este poderia ser submetido ao crivo de uma publicação e, em seqüencia estratificar a linha e pesquisa, pois nestas circunstâncias, já estaria devidamente habilitado para gerar um produção científica capaz de alcançar as mais elevadas qualificações. Assim, as linhas de pesquisa, já em pleno desenvolvimento, seriam então reavaliadas e seguiriam seu curso natural, sem ter nenhuma vinculação com qualquer setor ou área de especialização. Este pensamento teria como objetivo precípuo, simplificar $\mathrm{e}$, conseqüentemente, tornar mais ágeis os processos de avaliações dos Programas, que contemplam linhas de pesquisa e áreas de concentração de grande abrangência, permitindo desta forma, que todo tipo de produção se enquadre dentro das mesmas. Tal fenômeno, faz com que essas disciplinas disponham de denominações voltadas para o lato-sensu. Resalta-

1. Professor Adjunto do Departamento de Cirurgia da Faculdade de Medicina da UFRJ; Coordenador do Programa de Pós-Graduação em Cirurgia Geral da UFRJ. 
se, que apesar destas dificuldades, todos os Programas têm sido julgados sob regras pré-estabelecidas, dotadas de normas rígidas, para as avaliações, inicialmente individualizadas e, posteriormente, de forma comparativa.

Além do currículo nuclear obrigatório, que encampa, entre outras matérias: metodologia, planejamento, bio-estatística, bio ética etc., teríamos duas disciplinas no Mestrado e duas no Doutorado. Estas confeririam o embasamento teórico prático ao desenvolvimento das teses e dissertações e seriam especificadas pelo orientador.
Acreditamos que desta forma, não só estaríamos simplificando a estruturação dos Programas de Pós-Graduação além do que, propiciaríamos uma avaliação com critérios bem mais definidos.

Por fim, estamos tentando resgatar a situação de todos os titulados neste período de 30 anos, e deste modo, ter ciência de seus destinos e suas qualificações atuais. Uma ves mapeada esta condição, nos permitiremos colocar a questão sob o prisma da validade resultante de nossos esforços, no sentido de proporcionar uma melhor captação científica de nossos pares. 